\title{
Teaching to Connect: Community-Building Strategies for the Virtual Classroom
}

\author{
Sharla Berry \\ California Lutheran University
}

\begin{abstract}
A sense of community is central to student engagement and satisfaction. However, many students struggle with developing connections in online programs. Drawing on interviews with 13 instructors, this paper explores the strategies that they use to help students develop a sense of community in synchronous virtual classrooms. Four strategies for building community online are identified: reaching out to students often, limiting time spent lecturing, using video and chat as modes to engage students, and allowing class time to be used for personal and professional updates.
\end{abstract}

Keywords: community, community of inquiry, online learning, synchronous

Berry, S. (2019). Teaching to connect: Community-building strategies for the virtual classroom. Online Learning, 23(1), 164-183. doi:10.24059/olj.v23i1.1425

\section{Teaching to Connect: Community-Building Strategies for the Virtual Classroom}

While enrollment in higher education has declined overall, it has increased in one areadistance education (Allen \& Seaman, 2016). As of 2015, 29.8\% of American students in higher education had taken a distance course, and 14.4\% were enrolled in an exclusively distance education program. Twelve percent of undergraduates and $26 \%$ of postbaccalaureate students were enrolled in exclusively distance education programs (U.S. Department of Education, 2018). Despite these promising figures, attrition remains a challenge in online programs. Research by Jaggars and Bailey (2010) suggests that online attrition may be as much as $20 \%$ higher than in face-to-face programs. Community, defined as feelings of membership and closeness within a social group, can be a protective factor against online attrition (Angelino, Williams, \& Natvig, 2007; Tirrell \& Quick, 2012). Instructors, who are the primary point of contact for online students, play a central role in how online students develop a sense of community (Bolliger \& Halupa, 2012). Given the centrality of online faculty to students' experiences, their perspectives need to be captured in the research (Shea, Li, \& Pickett, 2006). Drawing on data from 13 faculty, this case study seeks to explore the strategies faculty used to enhance students' sense of community in one synchronous online doctoral program. 


\section{Review of Related Literature}

The growth in online programs represents an opportunity to expand access to higher education (Allen \& Seaman, 2016). Online programs allow colleges to expand their offerings to working professionals, rural students, and other learners who may have faced limitations of time or distance in attempting to pursue a degree. While supporters of online education have focused on the opportunity to provide increased content knowledge to diverse learners, there are many factors that an online program must attend to for success and sustainability. Students' interactions with content, technology, and support services all play a role in their experience of an online academic program (Berry, 2017a). Scholars also note that community is vital to students' engagement in a virtual academic program (Berry, 2017a; Rovai, 2003). A community can be defined as a supportive social group (Rovai, 2003). McMillan and Chavis (1986) write that a sense of community is "a feeling that members have of belonging, a feeling that members matter to one another and to the group, and a shared faith that members' needs will be met through their commitment to be together" (p. 9). In a learning community, participants have a shared goal, provide academic and social support to members, and work together to create learning artifacts or products and feel a sense of belonging (Lai, 2015).

A sense of community has academic and social benefits for students, in both online and on-the-ground programs (Lai, 2015; Lovitts, 2001; Rovai, 2003). Academic benefits of a sense of community include increased classroom participation and deep learning (Garrison, Anderson, \& Archer, 2010). The social benefits of community include an increased ability to manage stress and greater overall emotional well-being (Pyhältö, Stubb, \& Lonka, 2009; Stubb, Pyhältö, \& Lonka, 2011). Students who feel a sense of community are less likely to drop out of an academic program (Ke \& Hoadley, 2009).

Cultivating a sense of community can be difficult for online students (Ke \& Hoadley, 2009). Limited opportunities to interact with peers in person may increase feelings of distance and may undermine students' sense of connection in distance programs (Koslow \& Pina, 2015). Additionally, students may struggle with creating and maintaining friendships while trying to pursue personal and professional goals (Conrad, 2005).

Instructors, who are the primary point of contact for online students, can play a crucial role in how they cultivate a sense of community (Garrison, 2011). An instructors' facilitation style can impact students' experiences of community (Demmans Epp, Phirangee, \& Hewitt, 2017). Phirangee, Demmans Epp, and Hewitt (2016) found that students felt more connected when instructors took an active role in facilitating discussions. Rovai (2007) found that when online instructors created conditions where students could express themselves openly and present alternative viewpoints, students were more likely to feel a sense of community.

Instructors can also use coursework to help facilitate the development of community (Garrison, 2011). Waycott, Sheard, Thompson, and Clerehan (2013) found that assignments that require peer knowledge sharing can help students create connections online. Barak and Rafeli (2004) found that blogs, wikis, and discussion/message boards increased collaboration and peer support in online classes. Shea, Li, and Pickett (2006) found that teaching activities that encouraged deep reflection stimulated students' engagement in the learning community. Baran, Correia, and Thompson (2011) found that discussion-based strategies in online courses can reduce anxiety and increase participation. Martin and Bolliger (2018) found that small group discussions where students could think deeply and share meaningful insights increased student engagement. While some online students prefer working independently, many indicate that collaborative activities with peers can increase students' sense of community (Athens, 2018; Berry, 2017b). 
The method of delivery also impacts students' experiences. Though much of the literature on community explores asynchronous learning, research suggests that learning in a synchronous environment has benefits for student engagement (Pinsk, Curran, Poirier, \& Coulson, 2014). Abdelmalak (2017) found that integrating synchronous tools, such as Skype, with asynchronous tools, like Twitter, blogs, and wikis, could increase students' sense of community. Synchronous communication increased students' sense of intimacy and immediacy in the virtual classroom (Abdelmalak, 2017). Clark, Strudler, and Grove (2015) conducted a study where they compared students' experiences in asynchronous courses in which communication occurred through video posts with their experiences in synchronous courses in which students communicated through videoconferencing. In a videoconference, participants can use telephone communications to communicate in real time via audio and video. Students reported that the course that used synchronous videoconferencing helped them develop higher levels of social presence. Synchronous formats, particularly those that utilize video, change the way students interact at a distance. Lenblanc and Lindgren (2013) found that courses with synchronous video helped foreign language students communicate more easily, as they were able to understand what their peers were saying through interpreting nonverbal cues. The improved communication in turn increased these students' comprehension and sense of community. Videoconferencing is not the only reason that synchronous communication enhances community. Synchronous virtual classrooms can include many technical features that help students connect, including chat rooms, which enable text communication, and breakout rooms, which enable small group discussion. McDaniels, Pfund, and Barnicle (2016) found that these features helped students engage in a variety of ways and increased students' bonds in the virtual classroom. Synchronous learning also creates constraints in relationship to community. Martin and Bolliger (2018) found that students rated synchronous classrooms as either the most or least helpful facet of their online learning experience. Some students in their survey felt that the group discussions in real time enhanced their learning and stimulated their engagement, while others found the time commitment to be burdensome. McDaniels, Pfund, and Barnicle (2016) similarly found mixed reviews of synchronous learning. They found that some students enjoyed being able to communicate simultaneously through talk and text, while others struggled with managing multiple communication features at the same time. In an earlier study on the same degree program, Berry (2017b) found that instructors must be skilled in using synchronous platforms in ways that engage but do not overwhelm students. In that study, students suggested that the following practices contributed to their sense of community: creating a warm tone in the classroom, using technology to create a personalized learning experience, and skillfully integrating video and chat into synchronous discussions.

\section{Theoretical Framework}

The Community of Inquiry (CoI) framework (Garrison et al., 2010) provides a useful explanation of how community is developed in online classrooms. A meta-analysis by Rourke and Kanuka (2009) found that there have been over 250 empirical papers written utilizing the CoI framework. Using this framework links this research to a broader canon of education technology studies. In the CoI framework, community is fostered by three interdependent elements: social presence, teaching presence, and cognitive presence. Social presence is the ability of participants to establish themselves as real in a virtual environment (Garrison et al., 2010). Social presence is cultivated when students are supported in being authentic in the virtual classroom. This occurs when students are allowed to share elements of their personal and professional lives with instructors and peers (Garrison, 2011).

Teaching presence is the ability of instructors to facilitate connections online (Garrison et al., 2010). When instructors are authentic and supportive, they can connect with students and help 
facilitate peer interactions. Instructors can also use curriculum and instruction to facilitate connections (Garrison et al., 2010). Through implementing activities that require collaboration, interaction, and reflection, instructors can help students strengthen relationships with peers. Activities that help cultivate openness, trust, and support are critical to supporting students' sense of community. By creating opportunities for students to learn with and from each other, instructors cultivate strong teaching presence, help students develop social presence, and promote students' cognitive presence (Garrison, 2011).

Cognitive presence refers to the instructors' ability to facilitate moments of learning that are reflexive and provoke dialogue, and the ability of students to experience a learning environment where they can question, critique, and reflect with peers (Garrison et al., 2010). When cognitive presence is strong, students will feel like they worked collaboratively to meet shared academic goals. The CoI theoretical framework suggests that instructors who cultivate high levels of teaching presence, social presence, and cognitive presence in online classrooms will help students develop a sense of trust, belongingness, and self-disclosure (Garrison et al., 2010). Over time, these feelings will contribute to students' sense of community in virtual classrooms (Garrison et al., 2010).

\section{Research Question}

This paper is driven by the following question: What strategies do faculty use to help create community in an online program?

\section{Setting}

\section{Methods}

The study took place in an online doctoral program at a large Research 1 institution which will be referred to by the pseudonym University of the West. Data was drawn from the education doctoral program. Though this program was in its third year, the University of the West has been offering master's and doctoral programs in education for the past eight years.

The degree program used a synchronous format to deliver classes. Each class was held online once a week for approximately two hours. Courses were hosted using Adobe Connect web conferencing software. Through this software, students could see their peers and the instructor. The software also allowed students to be separated into smaller groups for discussions and to communicate via chat.

\section{Design}

The qualitative approach allows researchers to highlight participants' experiences in detail (Merriam, 2009). As there are few studies which capture the perspectives of online faculty, this approach was deemed appropriate. This study is a qualitative case study, where the case is the online doctoral program. Case study methods are appropriate for descriptive analyses of unique contexts (Merriam, 2009).

\section{Sample}

The study was open to all full-time and part-time faculty who taught in the spring 2017 semester of the program. Data collection began by soliciting participation from faculty who were in charge of leading a section of a course in that term. These key informants helped generate a snowball sample by recommending other faculty who should be invited to participate in the study. Participants were sought who represented a range of experiences in the online program, including 
newer and more experienced faculty. (Table 1 contains a profile of the sample.) After interviewing six full-time and seven part-time faculty (or $25 \%$ of the faculty who taught courses in spring semester), no new data emerged, and data collection ceased. Full-time faculty had an average of 12.5 years teaching experience in higher education and an average of seven years in online teaching experience. Part-time faculty had an average of nearly four years teaching experience in higher education and a little over three years in online teaching experience. Approval from the Institutional Review Board to conduct the study was received, and informed consent was obtained from all participants prior to data collection.

Table 1

Profile of Participants

$\begin{array}{llll}\begin{array}{l}\text { Faculty } \\ \text { (pseudonym) }\end{array} & \text { Part-time or full-time } & \begin{array}{l}\text { Years taught } \\ \text { online }\end{array} & \begin{array}{l}\text { Years taught in higher } \\ \text { education }\end{array} \\ \text { Dana } & \text { Full-time } & 8 & 20 \\ \text { Vanessa } & \text { Part-time } & 6 & 6 \\ \text { Michael } & \text { Full-time } & 7 & 7 \\ \text { Stacey } & \text { Full-time } & 8 & 8 \\ \text { Marie } & \text { Full-time } & 8 & 8 \\ \text { Jane } & \text { Part-time } & 4 & .5 \\ \text { Javier } & \text { Part-time } & 1 & 1 \\ \text { Davis } & \text { Part-time } & 1 & 1 \\ \text { Marty } & \text { Part-time } & 11 & 11 \\ \text { Susan } & \text { Part-time } & 1 & 1 \\ \text { Darren } & \text { Full-time } & 3.5 & 18 \\ \text { Ashley } & \text { Part-time } & 3 & 3 \\ \text { Kara } & \text { Full-time } & 8 & 14\end{array}$

\section{Data Collection}

Semistructured, 45-minute interviews were conducted with the 13 participants. Semistructured interviews allow researchers to stick to a protocol while allowing for deviations as necessary. The open-ended questions allowed faculty to share their unique experiences. The interviews focused on definitions of community, faculty's role in community, and strategies for creating community. The interview questions appear in Appendix A.

\section{Data Analysis}

Interviews were conducted via phone and recorded using GoogleVoice. Audio files were sent to a transcription service. The transcripts were analyzed using a coding scheme aligned to the CoI framework (Garrison, Anderson, \& Archer, 2010). A directed content analysis approach was used to analyze data (Hseih \& Shannon, 2005). In this approach, an existing theory is used to analyze data. Beginning with a coding scheme aligned to the CoI framework (see Appendix B), the researcher identified aspects of cognitive presence, teaching presence, and social presence. An example of social presence would be self-disclosure, where students or instructors share details of their personal lives outside of class. An example of teaching presence would be establishing 
netiquette through the creation of norms. An example of cognitive presence would be engaging in critical discourse about course content.

After analyzing the data with the pre-established codes, the interview transcripts were reviewed again for new codes that emerged from the data. Codes that emerged from participants' perspectives and that held across interviews were added to the coding scheme. For example, "checking in," or spending time at the start of class to learn about updates from students' personal and professional lives, was added to the coding scheme after it came up in several interviews. Data was recoded using theoretical and emergent codes. The themes that emerged from coded data were used to create the case study on faculty perspectives on community.

\section{Limitations}

This study has several limitations. First, the study focuses primarily on synchronous strategies for building community. As online programs use a variety of formats, including asynchronous and hybrid course delivery, the findings may not be applicable to contexts where students do not meet online in real time. Another limitation of the study is that it focuses on only one online program. Even within synchronous programs, there is wide variation. Comparative work is needed to see how the strategies outlined in this study are utilized in other programs.

\section{Results}

Faculty in the online program implemented a number of strategies to help students in the online program develop a sense of community. Four of the strategies are highlighted below: reaching out to students often, limiting the time spent lecturing, using video and chat as modes to engage students, and allowing class time to be used for personal and professional updates.

\section{Strategy 1: Reaching Out Early and Often}

Faculty in the online doctoral program agreed that the first step in helping form an online community was to connect with students. Toward that end, faculty were intent on reaching out early to begin fostering connections with students. All of the faculty sent welcome emails to introduce themselves to students. Here is how Michael describes his initial efforts to establish a tone of warmth and rapport early on with students:

Before the semester starts, I send the students an introductory email. In that email, I give some personal information about myself. We talk more about what I've shared when we do our first online class meeting. Throughout the semester, I make sure the students learn more about me. I'll share some personal stories and experiences and allow students to do the same. I think by the end of the class, my students know me pretty well, and I think I know them pretty well.

For Michael, the introductory email was a way to begin the process of building relationships with students. In addition to reaching out before the semester started, seven of the faculty described the importance of maintaining regular connection with distance learners over the course of the semester. Jane describes how she reached out to her students:

I send them at least one email a week, and I at least post to the wall one time per week. Just checking in, just sending email, using words like, "appreciate," "look forward to seeing you." So, I think the language that we use is so important as well.

Jane indicated that the content of the messages varied in response to students' needs: 
Oftentimes I send students a recap of the class and then the deliverables moving forward for that week. There are other times where it might be an announcement. So, for example, there's a video that somehow went missing in cyberspace for one of the units and I just gave them an update on that. So sometimes it's moving forward throughout the week, hearing things that we need to accomplish. Sometimes it's just an announcement. Sometimes it's, "I hope your week is going well. I look forward to seeing you all Saturday." Just reminding them the expectation before the class. So sometimes just check-in. Sometimes it's a reminder. Sometimes it's kind of those, for lack of better terms, marching orders for the week until I see them again.

For Jane, the weekly messages to her students were a way to keep a connection active between class sessions. The messages were also a way for her to express that she was interested in students' lives and available to quickly address their concerns. For Michael, Jane, and other faculty in the online program, sending messages at the start of the school year and throughout the course of the semester was a way to create and strengthen bonds with students.

\section{Strategy 2: Limiting Lecture Time, Increasing Discussion}

With the first strategy, instructors sought to strengthen the relationships they had with students. However, cultivating community is also about facilitating interactions between peers. Toward that end, faculty used a variety of teaching strategies to promote peer interaction in the online classes. One strategy was to limit time for lecture and increase time for discussion in the online classes. More than half of the faculty interviewed, including Marty, suggested that an overreliance on lecture was not productive for an online environment:

Teaching online is not just, "hey I'm gonna turn my computer on and my camera, and I'm just gonna be able to teach an online class." If you're lecturing for two hours, then that's a complete waste of everybody's time. If you're not giving students an opportunity to have a voice and an opinion, it's completely a waste of time for students.

Instead of relying on lecture as the primary mode of instruction, four of the online faculty opted for more of a flipped classroom model. In this model, students were encouraged to review course content independently and were expected to come to class ready to apply what they learned through small group activities. This model allows the instructor to act more as a facilitator than as a lecturer and frees up class time for student-led discussion. Jane talked about the importance of using a more discussion-based format in her online class sessions:

My online classes are less lecture and more conversation. It's more of a Socratic seminar in the sense that there's give and take as opposed to, "I'm the expert in the room and I'm gonna just give all my knowledge to you." I think it helps because there are so many perspectives in a doctoral class. I tell my students, "I know that you all bring these really unique experiences and I want to learn from you." And I think that they really appreciate that. I think that made them comfortable that I wasn't coming in as this expert in a sense. I think that's really helped with our dialogue in the class.

As Jane's quote illustrates, encouraging a conversation between students rather than an instructor-directed lecture was a way to encourage dialogue in the online classroom. Instructors suggested that frequent dialogue was central to promoting a sense of community in the online classroom. 


\section{Strategy 3: Using Multiple Technical Features of the Virtual Classroom to Encourage Discussion}

To facilitate robust, interactive online discussions, instructors had to utilize many of the features in the virtual classroom. The program at the University of the West utilized a system powered by Adobe Connect. Using this particular web conferencing software, teachers could break students into groups of varying size. Instructors could also use a chat room to have whole group or small group discussions. Instructors found that by using these functions in each of their online class meetings, they could help students cultivate a sense of community in the online classroom. In this particular online program, the chat room was a regularly used function that instructors could use to increase interaction. Six of the faculty used the chat as a space where students could engage in multiple, simultaneous discussions of course content. Kara would use the chat to identify strands of discussion that she could elaborate on with the whole group:

When I ask a question, oftentimes students will respond in the chat box. While we might have somebody who is verbal and says, "Hey, here's what I think", many students like to use the chat box. So I'll make it a habit to scan the chat. If I see something that is interesting or see someone who doesn't normally speak up and that I want to bring into the conversation, I'll ask that person to elaborate on what they mentioned in the chat box. So that gives me a chance to support the folks that are not necessarily instinctively verbal, and also to pick and choose the kind of responses that help guide the content. The chat is really big in engaging the students.

As Kara's quote suggests, using the chat was a way to broaden participation in the course discussion. Stacey also spoke about the democratizing effect that the chat room had on course discussions:

I like being able to communicate in multiple modalities simultaneously. For example, I might be facilitating a conversation out loud with the whole group of students, but while I'm doing that, I might also be talking via text in the chat pod to a few students who have a different question. The chat allows us to have a side channel, where a secondary conversation is happening. This is particularly helpful for students who choose to type more than talk, or students are English language learners or students who are feeling shy for whatever reason. A lot of times, students will communicate via chat before talking aloud. I can pull out things from the chat and highlight them, and respond to them more. This helps warm people up, it helps them engage more.

As Stacey's quote illustrates, the synchronous chat room fulfilled several functions in the online classroom. It allowed multiple conversations to happen simultaneously, increasing the number of students who could participate. It allowed for students who had difficulty expressing themselves verbally to engage in the whole group activities. The chat also helped increase students' comfort level with participating in the online classroom. All of the instructors interviewed said that they used the chat in each course session. By making regular use of the chat, instructors ensured that more students could participate in online discussions. By expanding participation in course discussions, instructors contributed to students' engagement in the online community.

While the chat was a way to strengthen students' interactions with the group as a whole, breakout rooms were a way to help students have deeper interactions with smaller groups of colleagues. Through the breakout function in the virtual classroom, instructors could place students in small groups to have discussions. All of the instructors said they frequently used the function to place students in groups ranging from two to four in number as a way to encourage peer interaction 
and strengthen the online community. Kara described the way that she used breakout rooms in the online classroom:

I believe that you have to position students as contributors to the discussion, as folks who have something to add to the conversation. So, I use breakout rooms every single class. I try to keep it to like two breakout sessions each class time, just because I know that it takes time to go into the breakout, to have time there to sufficiently discuss and then to come back. But I don't ever not have breakout sessions when I'm teaching online because I find that that is the best way in a small group format to engage students and to have them talking to each other.

The theme of breakout rooms as central to student engagement came up in 12 of the interviews with online faculty. Breakout rooms were also a way to encourage relationship building in the online program. For Marty, breakouts gave students the opportunity to get to know their colleagues:

In an online program, I think it is incumbent upon the professor to provide those opportunities for students to get to know one another, to work together. It's easy sometimes to let students work with the same folks every time because maybe they have a similar profession, work in the same industry, or naturally gravitate toward one another. But as an instructor in an online program, you have to be intentional about grouping students together to encourage connections. Sometimes I randomly sort students into groups, but most of the time I'm strategic. I can tell pretty quickly who knows who really well. I try to give students opportunities to work with others whom they work well with, but also to work with new students. I use the breakouts to build that sense of community and to deepen their capacity as individual students and as collaborators working together to learn something new.

According to instructors, the small group conversations that occur in the breakout rooms provide a space for students to go deeper with their colleagues. Michael described the impact of breakout rooms on his students' connections:

We are big on small group discussions and projects. In the small group interactions, I do think that you get sort of a friendship that comes from this and people sharing things. One of the things I do when I would break the students into small groups is I turn off my camera. When I went into the breakout rooms, they didn't know I was there; just to see what was going on. And I'll see the students sharing some personal experiences and personal stories. What they are talking about is not necessarily related to the assignment, but was actually still neat to see them connecting.

As Michael's quote illustrates, the breakout groups produced interactions that were both academic and social in nature. By providing a space for students to work collaboratively while also having fun and learning about peers, instructors' use of the breakout rooms helped strengthen students' sense of community.

\section{Strategy 4: Using Class Time to Share Personal and Professional Updates}

As the previous strategies indicate, faculty in the online doctoral program at the University of the West spoke frequently about using a range of strategies to encourage dialogue surrounding academic content. Through these discussions students were afforded space to interact and bond with their peers, contributing to their sense of community. However, not all of the dialogue in the online classroom was related to academics. Half of the faculty interviewed were intentional about allowing more informal, personal, and social discussion to take place in the online class. Jane described the importance of responding to students' needs for social interaction this way: 
The feedback from my students was that they wanted more time for informal interaction in their classes. Because of the cohort model, students were taking classes together, and so they were bonding intellectually. But the students told me that they wanted more time to bond informally. I think there is a sense of connection when students can talk more freely in the class.

To help students cultivate a sense of community, Jane allowed students to "talk freely" throughout the class, which included allowing opportunities during class for students to ask questions, share concerns, and share information that was not directly related to course content. For Ashley, this looked like carving out time for informal discussion at the start of each class session:

I think students in our online program have a huge desire to connect and to really network, for lack of a better term. Students want to share information and help each other with opportunities. To help with this, I always put up different poll questions before my class starts. One of the questions I'll ask is something like, "Who do you know who would be a great contact for your colleagues?" Something like that, so that they can have this kind of discussion about it. We spend maybe five or ten minutes on this. Some students come to the class early, and so I don't want them just sitting waiting for us to start, I want them to be busy. So, asking questions at the beginning of class gives the early students an opportunity to connect with each other and learn something from their peers as well.

Ashley was intentional about carving out space at the start of the online class for students to ask targeted, purposeful questions to peers that met academic and professional needs. Other online faculty used the first few minutes of class to allow for more organic social discussion to take place. Kara described a common exchange in her class that emphasizes this more organic flow:

I have a current student who is in Kuwait, he just moved to Toronto for the summer, but the first couple of weeks he was in Kuwait so he was waking up at 2:00 in the morning. So, he looked a little disheveled and tired and I would allow students to converse about, "How are you doing Steven? Are you awake?" And things like that to enable students to not just think of classes as just a place for instruction. While it's important for me to spend the bulk of the time on the content so that they get their money's worth, I do allow for some time to check-in about personal things and how people are doing.

For Kara and for other faculty, it was important for students to see the online classroom as a social and interactive space, one where academic content was prioritized but personal sharing was encouraged. One facilitation strategy Marty used to prioritize social engagement in the online classroom was to use the first few minutes of each online class session to allow the students to share personal updates with their peers. Here is how Marty described this process:

At the beginning of every semester, we do course introductions. I let the students know my background, my expertise, my area of interests I also dedicate a portion of every class to sharing updates. We start class with celebrations, personal and professional. So sometimes not all students have something to share, but I always make a point to share something about myself to model that so they feel safe to share something of success in the last week, either personally or professionally, so they get to know me there. I also share helpful information that is not necessarily related to the curriculum. For example, I'll talk to them a little bit about the EdD program, how to navigate it, how to be a successful student, and how to complete a dissertation. I share information from my own doctoral journey. 
For Marty, sharing his personal experiences was a way that he could connect with doctoral students. By sharing highlights from his own doctoral journey, he was able to build rapport with students. By allowing students to share elements of their personal and professional interests in class, Marty and other faculty helped cultivate a sense of intimacy and authenticity, two crucial components to community.

\section{Discussion and Implications}

Findings from this study indicate alignment between what instructors and students considered to be community-building strategies (Berry, 2017b). Reaching out early and often, using class time to allow students to share personal and professional updates, and skillfully using technology to engage with students were strategies that students cited as being beneficial to their sense of community (Berry, 2017b). That instructors similarly view those as valuable strategies is important for the sustainability of such practices in the classroom. In the first study, students did speak about the importance of personalization, including instructors who gave them audiorecorded feedback and did other things to tailor the classroom to their individual interests. Such themes of personalization did not come up when talking to instructors, and therefore require further inquiry.

Another area of departure on the nature of community-building came in considering where community is cultivated. Data collected from faculty suggested that online instructors feel that community for online students is limited to the classroom. However, previous research on students in the online doctoral program suggests that they experience community in a variety of spaces (Berry, 2017a). Students in this program connected online through social media. They also connected in person, meeting up for study groups in the library and attending football games together (Berry, 2017a). Instructors in this study were largely unaware of student interactions outside of the classroom, and were not aware of the significance of these events in cultivating students' sense of community. Findings collected in this study suggest a disconnect in how online instructors and students view the online experience. In order to support students' sense of community more fully, instructors must be aware of the nature of student engagement in the program in which they teach. While instructors were very attentive to the dynamics of community for which they were directly responsible, there may have been missed opportunities to help support student engagement in the academic program as a whole (Berry, 2017a). Learning more about instructors' roles in supporting students' sense of community outside of online classrooms is a key area for research and theory-building.

The findings of this study connect to theory in other ways as well. In the CoI framework, Garrison, Anderson, and Archer (2010) write that an online community is cultivated through instructors' ability to help students be authentic in virtual environments (social presence), effectively use the medium to teach and promote peer interaction (teaching presence), and help students make connections between academic content and their personal and professional experience. Instructors in this particular program cultivated community in ways that were consistent with Garrison, Anderson, and Archer's work on social presence and teaching presence. What is important to note in this case study is the overlapping nature of social presence and teaching presence. Much of instructors' efforts to help students connect in the classroom relied on altering the structure of teaching activities to increase opportunities for social interaction. From devoting class time to sharing personal updates to utilizing a flipped classroom to allow for more discussion, instructors were intentional about creating opportunities for social engagement between students throughout each course session. 
Instructors' efforts to use instructional time to cultivate social presence may have contributed to students' sense of community in the online program. However, research by Ke (2010), Shea and Bidjerano (2009), and Diaz, Swan, Ice, and Kupczynski (2010) suggests that the impact of social presence on cultivating a community of inquiry may be overstated. Ke (2010) writes that students may prefer reduced discussion with peers in favor of more rigorous academic activities. Martin and Bolliger (2018) found that online students had varying perspectives on the benefits of peer discussion, with some feeling it was the most beneficial aspect of online learning, and others feeling like it was the least beneficial component of distance education. While instructors in this study felt that using peer interaction as a means of cultivating social presence was beneficial to students, more research needs to be done on students' perceptions of the importance of peer discussion and interaction.

While strategies that increased social and teaching presence were foregrounded in this particular study, a limitation of this work is that instructors provided less information on how they developed cognitive presence in the online community. Redmond et al. (2018) writes that cognitive engagement is a central part of engaging students online. Activating metacognition is a powerful tool to help distance learners connect to the curriculum and to each other (Garrison et al., 2010). Ke (2010) writes that strong cognitive presence in an online classroom is associated with higher social presence and an increased sense of community. While instructors may seek to increase higher order thinking for individual learners, more research needs to be done on how instructors use critical thinking exercises to help students work collaboratively to make collective meaning of content and explore the implications of collaborative cognitive engagement on students' sense of community (Lee, 2014).

\section{Conclusion}

By highlighting teaching strategies that online instructors find effective, this study contributes to the literature on best practices in online learning. The findings from this case study indicate that some instructors are presently using the strategies that other researchers have found beneficial in online learning environments. For example, instructors were committed to increasing discussion and peer interaction in the distance learning environment, goals that have been identified as best practices in distance learning (Garrison, 2011; Rovai, 2007). Additionally, researchers made efforts to use multimodal communication, including videoconferencing and chat rooms. The use of multiple modes of communication has been found effective in some contexts, and warrants further inquiry (Abdelmalak, 2017; Clark, Strudler, \& Grove, 2015). The fact that online faculty are taking steps to promote interactivity in distance environments indicates the integration of best practices into online classes, at least in one particular program.

This research also advances the best practices literature in a new way, as it highlights the importance of personalization and sociability to the online learning experience as promising practices. In this case study, instructors sought to increase personal connections to individual students by sending them emails before and during the semester to check in. Instructors also increased the social experience of the online class as a whole by allowing students to learn about their peers' personal and professional interests. Previous research on students in these classes suggests that these efforts to learn about students to bring different aspects of their lives into the virtual classroom enhanced students' sense of community (Berry, 2017b). While more research needs to be done on the efficacy and outcomes of these practices, early research on this area suggests that students would identify these activities as best practices for online environments (Berry, 2017b). 
The results of this study can be used by educators and administrators who are looking to improve teaching practice. Teaching online requires that instructors use a range of strategies to connect with students. The findings of this study suggest that these strategies cannot focus solely on academic content (Banna et al., 2015) but instead must factor in a broad range of students' social and emotional needs. By highlighting strategies that have been field tested by practitioners, this research can support the professional development of online faculty.

While exploring online teaching practices in depth is a critical first step in improving the delivery of online learning, more research needs to be done regarding students' perceptions of the efficacy of those teaching practices (Martin \& Bollinger, 2018). Additionally, more research is needed on how instructors' strategies to build cognitive presence impact students' sense of community. By continuing to highlight faculty and student perspectives on teaching and learning online, researchers can strengthen practice in a growing sector of higher education. 


\section{References}

Abdelmalak, M. M. M. (2015). Web 2.0 technologies and building online learning communities: Students' perspectives. Online Learning, 19(2).

Allen, I. E., Seaman, J., Poulin, R., \& Straut, T. T. (2016). Online report card: Tracking online education in the United States. Babson Park, MA: Babson Survey Research Group and Quahog Research Group, LLC.

Alvarez, I., Espasa, A., \& Guasch, T. (2012). The value of feedback in improving collaborative writing assignments in an online learning environment. Studies in Higher Education, 37(4), 387-400.

Angelino, L. M., Williams, F. K., \& Natvig, D. (2007). Strategies to engage online students and reduce attrition rates. Journal of Educators Online, 4(2).

Athens, W. (2018). Perceptions of the persistent: Engagement and learning community in underrepresented populations. Online Learning, 22(2), 27-58. doi:10.24059/olj.v22i2.1368

Banna, J., Lin, M.-F. G., Stewart, M., \& Fialkowski, M. K. (2015). Interaction matters: Strategies to promote engaged learning in an online introductory nutrition course. Journal of Online Learning and Teaching, 11(2), 249-261.

Barak, M., \& Rafaeli, S. (2004). On-line question-posing and peer-assessment as means for webbased knowledge sharing in learning. International Journal of Human-Computer Studies, 61(1), 84-103.

Baran, E., Correia, A. P., \& Thompson, A. (2011). Transforming online teaching practice: Critical analysis of the literature on the roles and competencies of online teachers. Distance Education, 32(3), 421-439.

Berry, S. (2017a). Exploring community in an online doctoral program: A digital case study. Proquest.

Berry, S. (2017b). Building community in online doctoral classrooms: Instructor practices that support community. Online Learning, 21(2). doi:10.24059/olj.v21i2.875

Black, E. W., Dawson, K., \& Priem, J. (2008). Data for free: Using LMS activity logs to measure community in online courses. The Internet and Higher Education, 11(2), 65-70.

Bolliger, D. U., \& Halupa, C. (2012). Student perceptions of satisfaction and anxiety in an online doctoral program. Distance Education, 33(1), 81-98.

Clark, C., Strudler, N., \& Grove, K. (2015). Comparing asynchronous and synchronous video vs. text based discussions in an online teacher education course. Online Learning, 19(3), 4869.

Conrad, D. (2005). Building and maintaining community in cohort-based online learning. Journal of Distance Education, 20(1), 1-20.

Demmans Epp, C., Phirangee, K., \& Hewitt, J. (2017). Student actions and community in online courses: The roles played by course length and facilitation method. Online Learning, 21(4), 53-77. doi:10.24059/olj.v21i4.1269 
Dunlap, J. C., \& Lowenthal, P. R. (2014). The power of presence: Our quest for the right mix of social presence in online courses. Real life distance education: Case studies in practice, 41-66.

Garrison, D. R. (2011). E-learning in the 21st century: A framework for research and practice. New York: NY. Routledge.

Garrison, D. R., Anderson, T., \& Archer, W. (2010). The first decade of the community of inquiry framework: A retrospective. The Internet and Higher Education, 13(1), 5-9.

Hsieh, H. F., \& Shannon, S. E. (2005). Three approaches to qualitative content analysis. Qualitative Health Research, 15(9), 1277-1288.

Jaggars, S. S., \& Bailey, T. (2010). Effectiveness of fully online courses for college students: Response to a Department of Education meta-analysis. New York, NY: Columbia University, Teachers College, Community College Research Center.

Kang, H. (2012). Training online faculty: A phenomenology study. International Journal on ELearning, 11(4), 391-406.

Ke, F. (2010). Examining online teaching, cognitive, and social presence for adult students. Computers \& Education, 55(2), 808-820.

Ke, F., \& Hoadley, C. (2009). Evaluating online learning communities. Educational Technology Research and Development, 57(4), 487-510.

Koslow, A., \& Piña, A. A. (2015). Using transactional distance theory to inform online instructional design. Instructional Technology, 12(10), 63-72.

Lai, K. W. (2015). Knowledge construction in online learning communities: A case study of a doctoral course. Studies in Higher Education, 40(4), 561-579.

Leblanc, A., \& Lindgren, C. (2013). Development of on-line courses focusing on quality. In Proceedings - The Open and Flexible Higher Education Conference 2013.

Lee, S. M. (2014). The relationships between higher order thinking skills, cognitive density, and social presence in online learning. The Internet and Higher Education, 21, 41-52.

Lovitts, B. E. (2001). Leaving the Ivory Tower: The causes and consequences of departure from doctoral study. Lanham, Maryland: Rowman \& Littlefield .

Martin, F., \& Bolliger, D. U. (2018). Engagement matters: Student perceptions on the importance of engagement strategies in the online learning environment. Online Learning, 22(1). Retrieved from https://olj.onlinelearningconsortium.org/index.php/olj/article/view/1092/371

McDaniels, M., Pfund, C., \& Barnicle, K. (2016). Creating dynamic learning communities in synchronous online courses: One approach from the Center for the Integration of Research, Teaching and Learning (CIRTL). Online Learning, 20(1), 110-129.

McMillan, D. W., \& Chavis, D. M. (1986). Sense of community: A definition and theory. Journal of Community Psychology, 14(1), 6-23.

Merriam, S. B. (2009). Qualitative research: A guide to design and implementation. San Francisco, CA: Jossey-Bass. 
Phirangee, K., Demmans Epp, C., \& Hewitt, J. (2016b). Exploring the relationships between facilitation methods, students' sense of community and their online behaviours. Online Learning Journal, 20(2). http://dx.doi.org/10.24059/olj.v20i2.775

Pinsk, R., Curran, M., Poirier, R., \& Coulson, G. (2014). Student perceptions of the use of student-generated video in online discussions as a mechanism to establish social presence for non-traditional students: A case study. Issues in Information Systems, 15, 267-276.

Pyhältö, K., Stubb, J., \& Lonka, K. (2009). Developing scholarly communities as learning environments for doctoral students. International Journal for Academic Development, 14(3), 221-232.

Rourke, L., \& Kanuka, H. (2009). Learning in communities of inquiry: A review of the literature. International Journal of E-Learning \& Distance Education, 23(1), 19-48.

Rovai, A. (2003). In search of higher persistence rates in distance education online programs. The Internet and Higher Education, 6(1), 1-16.

Rovai, A. (2007). Facilitating online discussions effectively. The Internet and Higher Education, 1(1) $77-88$.

Saldaña, J. (2012). The coding manual for qualitative researchers. Thousand Oaks, CA: SAGE.

Shea, P., Li, C. S., \& Pickett, A. (2006). A study of teaching presence and student sense of learning community in fully online and web-enhanced college courses. The Internet and Higher Education, 9(3), 175-190.

Solorzano, D., Ceja, M., \& Yosso, T. (2000). Critical race theory, racial microaggressions, and campus racial climate: The experiences of African American college students. Journal of Negro Education, 60-73.

Stubb, J., Pyhältö, K., \& Lonka, K. (2011). Balancing between inspiration and exhaustion: $\mathrm{PhD}$ students' experienced socio-psychological well-being. Studies in Continuing Education, $33(1), 33-50$.

Tirrell, T., \& Quick, D. (2012). Chickering's seven principles of good practice: Student attrition in community college online courses. Community College Journal of Research and Practice, 36(8), 580-590.

Torres, V., Jones, S. R., \& Renn, K. A. (2009). Identity development theories in student affairs: Origins, current status, and new approaches. Journal of College Student Development, 50(6), 577-596.

U.S. Department of Education, National Center for Education Statistics. (2018). Digest of Education Statistics, 2016 (NCES 2017-094), Table 311.15. Retrieved from https://nces.ed.gov/programs/digest/d16/tables/dt16 311.15.asp?current=yes

Waycott, J., Sheard, J., Thompson, C., \& Clerehan, R. (2013). Making students' work visible on the social web: A blessing or a curse? Computers \& Education, 68, 86-95. 


\section{Appendix A}

Interview Protocol

1. What is your name? What is your title? How long have you been at the University of the West?

2. How long have you been teaching online? Describe positions held at University of the West and elsewhere.

3. How would you describe the experience? Specifically, how does teaching online differ from teaching face-to-face? Are there unique challenges associated with teaching online?

4. According to the literature, one challenge that online students experience is creating community. How would you define a learning community?

5. What would you say is the instructor's role in creating community online?

6. Based on the literature, community is defined as a site of frequent interaction, engagement, and mutual support. In a community, members trust each other and support each other toward shared goals. Would you describe your classes in the program as learning communities? Why? Why not? Can you give examples?

7. Inside the classroom, what do you do to promote peer interaction and connection? Are there teaching strategies, assignments, etc. Can you give examples?

8. What strategies do you use to facilitate dialogue and discussion in your classes? What activities do you use to promote reflection and critical thinking in the online class?

9. As an instructor, what is your role in supporting students' sense of community in your classes? Do you play a role in supporting their sense of community outside of class? How?

10. Switching reels for a second to talk about technology design... the LMS features a number of bells and whistles including video and chat... how do the features of LMS impact how you help students connect and engage?

11. Do you use features like breakout rooms in your class? How often? How do you think it impacts students' interaction and sense of community? Do you use the chat room in your classes? How often? What about chat? How do you think the use of chat in your classroom impacts students' sense of community? Are there features you'd like to use more in the synchronous classroom? Why?

12. Did you receive any training professional development in using features of the LMS? Describe. How did it impact your teaching practice?

13. Thinking more broadly about the program and the institution, are there any supports that assist you in facilitating community? For example, are their resources, professional development or collaboration opportunities that have impacted how you support students in connecting and interacting in the classroom?

14. Talk about your experience as a faculty member... Are there any things that you experience as a faculty member that make it harder for you to facilitate community? These can be experiences inside of the classroom or outside of the classroom.

15. How are full-time faculty (or adjunct faculty) expected to help cultivate community in the online program? How do you feel about these expectations? What resources have you received to support you in creating community? What barriers have you experienced in trying to create community?

16. Overall, what resources do you think online faculty need in helping facilitate peer-to-peer interaction, engagement and community?

17. Is there anything else we have not mentioned about creating and maintaining online community that you would like to add? 


\section{Appendix B}

Coding Scheme

Note: This coding scheme is taken from Garrison, D. R., Anderson, T., \& Archer, W. (2010). The first decade of the community of inquiry framework: A retrospective. The Internet and Higher Education, 13(1), 5-9.

\begin{tabular}{|c|c|c|c|}
\hline Category & Code & Subcode & Definition \\
\hline $\begin{array}{l}\text { Social } \\
\text { presence }\end{array}$ & & & $\begin{array}{l}\text { Social presence is the ability of learners to } \\
\text { project their personal characteristics into the } \\
\text { community of inquiry, thereby presenting } \\
\text { themselves as 'real people.' }\end{array}$ \\
\hline \multirow[t]{4}{*}{$\begin{array}{l}\text { Social } \\
\text { presence }\end{array}$} & $\begin{array}{l}\text { Interpersonal } \\
\text { communication }\end{array}$ & & \\
\hline & & $\begin{array}{l}\text { Interpersonal } \\
\text { communication }\end{array}$ & $\begin{array}{l}\text { Conventional expressions of emotion, } \\
\text { including repetitious punctuation, conspicuous } \\
\text { capitalization, emoticons }\end{array}$ \\
\hline & & Self-disclosure & $\begin{array}{l}\text { Presents biographies, details of personal life } \\
\text { outside of class or expresses vulnerability }\end{array}$ \\
\hline & & Use of humor & $\begin{array}{l}\text { Teasing, cajoling, irony, understatements, } \\
\text { sarcasm }\end{array}$ \\
\hline \multirow[t]{9}{*}{$\begin{array}{l}\text { Social } \\
\text { presence }\end{array}$} & $\begin{array}{l}\text { Open } \\
\text { communication }\end{array}$ & & \\
\hline & & Continuing a thread & $\begin{array}{l}\text { Using reply features to quote others' entire } \\
\text { messages, or cutting and pasting selections of } \\
\text { others' messages }\end{array}$ \\
\hline & & $\begin{array}{l}\text { Quoting from } \\
\text { others messages }\end{array}$ & $\begin{array}{l}\text { Using software features to quote others' entire } \\
\text { messages, or cutting and pasting selections of } \\
\text { others messages }\end{array}$ \\
\hline & & $\begin{array}{l}\text { Referring explicitly } \\
\text { to others' messages }\end{array}$ & Direct references to contents of others' posts \\
\hline & & Asking questions & $\begin{array}{l}\text { Students ask questions of other students or the } \\
\text { moderator }\end{array}$ \\
\hline & & $\begin{array}{l}\text { Complementing, } \\
\text { expressing } \\
\text { appreciation }\end{array}$ & $\begin{array}{l}\text { Complimenting others or contents of others' } \\
\text { messages }\end{array}$ \\
\hline & & $\begin{array}{l}\text { Expressing } \\
\text { agreement }\end{array}$ & $\begin{array}{l}\text { Expressing agreement with others or content of } \\
\text { others messages }\end{array}$ \\
\hline & $\begin{array}{l}\text { Cohesive } \\
\text { communication }\end{array}$ & Vocatives & $\begin{array}{l}\text { Addressing or referring to participants by } \\
\text { name }\end{array}$ \\
\hline & & $\begin{array}{l}\text { Addresses or refers } \\
\text { to the group using } \\
\text { inclusive pronouns }\end{array}$ & Addresses the group as we, us, our, group \\
\hline
\end{tabular}




\begin{tabular}{|c|c|c|c|}
\hline Category & Code & Subcode & Definition \\
\hline \multirow[t]{4}{*}{$\begin{array}{l}\text { Teaching } \\
\text { presence }\end{array}$} & & & $\begin{array}{l}\text { Teaching presence is defined as the design, } \\
\text { facilitation, and direction of cognitive and } \\
\text { social processes for the purpose of realizing } \\
\text { personally meaningful and educational } \\
\text { worthwhile learning outcomes. }\end{array}$ \\
\hline & $\begin{array}{l}\text { Instructional } \\
\text { design and } \\
\text { organization }\end{array}$ & Setting curriculum & \\
\hline & & Designing methods & \\
\hline & & $\begin{array}{l}\text { Establishing time } \\
\text { parameters }\end{array}$ & \\
\hline \multirow[t]{3}{*}{$\begin{array}{l}\text { Teaching } \\
\text { presence }\end{array}$} & $\begin{array}{l}\text { Instructional } \\
\text { design and } \\
\text { organization }\end{array}$ & $\begin{array}{l}\text { Utilizing medium } \\
\text { effectively }\end{array}$ & \\
\hline & & $\begin{array}{l}\text { Establishing } \\
\text { netiquitte }\end{array}$ & \\
\hline & & $\begin{array}{l}\text { Making macro level } \\
\text { contents about } \\
\text { course content }\end{array}$ & \\
\hline \multirow[t]{7}{*}{$\begin{array}{l}\text { Teaching } \\
\text { presence }\end{array}$} & $\begin{array}{l}\text { Facilitating } \\
\text { discourse }\end{array}$ & $\begin{array}{l}\text { Identifying areas of } \\
\text { agreement/ } \\
\text { disagreement }\end{array}$ & \\
\hline & & $\begin{array}{l}\text { Seeking to reach } \\
\text { consensus/ } \\
\text { understanding }\end{array}$ & \\
\hline & & $\begin{array}{l}\text { Encouraging, } \\
\text { acknowledging or } \\
\text { reinforcing student } \\
\text { contributions }\end{array}$ & \\
\hline & & $\begin{array}{l}\text { Setting climate for } \\
\text { learning }\end{array}$ & \\
\hline & & $\begin{array}{l}\text { Drawing in } \\
\text { participants, } \\
\text { prompting } \\
\text { discussions }\end{array}$ & \\
\hline & & $\begin{array}{l}\text { Assessing the } \\
\text { efficacy of the } \\
\text { process }\end{array}$ & \\
\hline & & Engaging dialogue & \\
\hline
\end{tabular}




\begin{tabular}{|c|c|c|c|}
\hline Category & Code & Subcode & Definition \\
\hline \multirow[t]{7}{*}{$\begin{array}{l}\text { Teaching } \\
\text { presence }\end{array}$} & $\begin{array}{l}\text { Direct } \\
\text { instruction }\end{array}$ & $\begin{array}{l}\text { Present } \\
\text { content/questions }\end{array}$ & \\
\hline & & $\begin{array}{l}\text { Focus the } \\
\text { discussion on } \\
\text { specific issues }\end{array}$ & \\
\hline & & $\begin{array}{l}\text { Summarize the } \\
\text { discussion }\end{array}$ & \\
\hline & & $\begin{array}{l}\text { Confirming } \\
\text { understanding } \\
\text { through assessment } \\
\text { and explanatory } \\
\text { feedback }\end{array}$ & \\
\hline & & $\begin{array}{l}\text { Diagnose } \\
\text { misconceptions }\end{array}$ & \\
\hline & & $\begin{array}{l}\text { Inject knowledge } \\
\text { from diverse } \\
\text { sources, e.g., } \\
\text { textbook, articles, } \\
\text { Internet, personal } \\
\text { experiences } \\
\text { (includes pointers } \\
\text { to resources) }\end{array}$ & \\
\hline & & $\begin{array}{l}\text { Responding to } \\
\text { technical concerns }\end{array}$ & \\
\hline $\begin{array}{l}\text { Cognitive } \\
\text { presence }\end{array}$ & & & $\begin{array}{l}\text { Cognitive presence is the extent to which the } \\
\text { participants in any particular configuration of a } \\
\text { community of inquiry are able to construct } \\
\text { meaning through sustained communication. }\end{array}$ \\
\hline
\end{tabular}

\section{Emergent Codes}

\begin{tabular}{|l|l|l|}
\hline Code & Subcode & Definition \\
\hline $\begin{array}{l}\text { Social/emotional } \\
\text { support }\end{array}$ & $\begin{array}{l}\text { The process of asking questions and } \\
\text { providing answers that were relevant to } \\
\text { students' social and emotional needs }\end{array}$ \\
\hline $\begin{array}{l}\text { Creating a } \\
\text { personalized } \\
\text { learning experience }\end{array}$ & $\begin{array}{l}\text { The process of asking questions or } \\
\text { providing feedback that was tailored to } \\
\text { the needs of an individual student }\end{array}$ \\
\hline Checking in & $\begin{array}{l}\text { The process of asking students to share } \\
\text { their feelings with the class }\end{array}$ \\
\hline
\end{tabular}

